\title{
The influence of informal learning opportunities on adolescents' financial literacy
}

\author{
Michelle Rudeloff* (1)
}

\section{${ }^{*}$ Correspondence:}

michelle.

rudeloff@uni-tuebingen.de

Chair of Economic Education,

Eberhard Karls University

of Tübingen, Melanchthonstr.

30, 72074 Tübingen,

Germany

\begin{abstract}
In today's service society, adolescents come into contact with money and financial products and services earlier and earlier. Despite the importance of the topic in the adolescents' lives, there is insufficient evidence on the learning opportunities adolescents use outside of school and education to obtain information on financial issues and how these affect their financial competence. This paper investigates how different informal learning opportunities influence grade 10-students' financial literacy. Data are available for $\mathrm{N}=530$ students in general education. The analyses are based on a structural equation model in which financial literacy is represented as a latent variable with the sub-dimensions of money/payments, savings, loans, insurance, and monetary policy. Young people use different learning opportunities depending on the sub-dimension. Overall, parent-student discussions on finance are the most important informal source of learning. Discussions with siblings as well as consulting sessions with banks and media learning opportunities are also significantly related to financial literacy. Furthermore, personal characteristics, such as socio-economic background and economic interest, are also associated with financial literacy. The findings provide important implications for the promotion of financial literacy in different formal and informal learning situations. The results can be used, among other things, as a basis for developing targeted strategies to promote financial literacy in both the extracurricular sector and the school context.
\end{abstract}

Keywords: Financial literacy, Informal learning opportunities, Structural equation models

\section{Introduction}

In today's modern service society, the population's financial literacy is becoming increasingly important. The ability to deal with money and financial issues has long since ceased to play a role for only adults, but is relevant for even adolescents. Nowadays, adolescents are exposed to financial services earlier and earlier, such as within the framework of mobile phone contracts or their own bank accounts (OECD 2017a). The phase of transition to upper secondary level in particular poses a challenge for young people in this context (Bender 2012). For example, young people have to decide (with the help of their parents) whether they want to start vocational training or continue school, taking into account their current and future financial needs. Moreover, many students also earn some money by having small jobs outside of school hours or by taking on occasional jobs such as babysitting or gardening (OECD 2017a). Therefore, in this phase of

(c) The Author(s) 2019. This article is distributed under the terms of the Creative Commons Attribution 4.0 International License (http://creativecommons.org/licenses/by/4.0/), which permits unrestricted use, distribution, and reproduction in any medium, provided you give appropriate credit to the original author(s) and the source, provide a link to the Creative Commons license, and indicate if changes were made. 
young people's lives, the development of sufficient general financial education is of central importance.

Against this background, early promotion of the financial literacy of children and young people within the framework of a school curriculum appears necessary (Bender 2012; Schürkmann 2017), although curricular analyses show that financial content is not sufficiently anchored (Rudeloff 2019). This result applies to the different types of schools in the general school system in Germany. ${ }^{1}$ Nevertheless, young people have a certain knowledge of finance and financial management (Schürkmann 2017). Consequently, it is reasonable to assume that informal learning plays a decisive role in the acquisition of financial competencies beyond formal learning (Macha et al. 2011).

Informal learning can be defined as competence development that is not structured in terms of learning objectives, learning time or learning support and usually does not lead to certification. It can be both targeted, but also non-intentional and thus random (Commission of the European Communities 2001). However, it is crucial that such random or non-intential learning episodes are reflected retrospectively by the learner and at least perceived retrospectively (Overwien 2000; Marsick and Watkins 1992). For informal learning, learning opportunities are not organized by an educational institution (e.g. school). Against this background, informal learning can also be described as noninstitutional learning (Harring et al. 2016). In contrast, formal learning takes place in educational institutions such as schools, colleges and universities, but also in institutions of continuing vocational education and training (Düx and Rauschenbach 2010). Formal learning is structured in terms of learning objectives, learning content and learning support and its results are regularly certified. It is intentional from the perspective of the learner and is therefore highly conscious (Commission of the European Communities 2000). For the purpose of this paper, a learning opportunity represents an episode from the world in which young people live, which offers the possibility of (informally) acquiring financial knowledge (Rudeloff 2019). The learning opportunity could both be located in informal as well as formal settings; this article focuses on informal learning opportunities. Consequently, teaching in school is, for example, a formal learning opportunity. On the contrary, conversations with parents, siblings and friends are usually informal learning opportunities. As elaborated above, it does not matter whether the conversations are connected with the intention to learn something since the subsequent reflection of the learning process transforms an initially unconscious learning situation into an informal learning opportunity. The role of informal learning for the development of financial competencies has been increasingly investigated (e.g., Schuhen and Kunde 2015). New studies on financial literacy (e.g., OECD 2017a; Schürkmann 2017) also explicitly point out that, today, financial literacy is more often acquired through direct experience in dealing with money and financial services. Thus, the importance of informal learning opportunities is increasingly recognized. Further research efforts are needed to assess the significance of informal, i.e. non-institutional, learning opportunities for the acquisition of financial literacy. There is currently insufficient evidence regarding the learning

${ }^{1}$ The German school system is highly diverse. It includes different school types, such as lower secondary education, middle school, integrated comprehensive school, and grammar school. 
opportunities adolescents use to obtain information on financial issues and how such opportunities are related to different dimensions of financial literacy.

In order to address this research gap, this paper aims to answer the following research question: How do informal learning opportunities influence the development of financial literacy? To answer the question, the paper is structured as follows: The section "Financial literacy in the scientific discourse" will provide a concise overview of competence measurement and modelling in the financial domain, focusing on the presentation of variables related to financial literacy, especially informal learning opportunities. The "Research design" section deals with the test instrument, sample, available data, and evaluation methodology. Subsequently, the findings are presented in the "Results" section and critically examined in the final sections, "Discussion" and "Conclusion."

\section{Financial literacy in scientific discourse}

\section{Conceptual foundation of financial literacy}

Although a number of relevant national and international studies exist, some differ considerably in their conceptual design (Aprea 2012; Kaminski and Friebel 2012) due to the fact that these studies refer to different constructs (e.g., financial knowledge, financial literacy, financial education, or financial capability) that are not uniformly defined in the literature (Aprea 2012; Liening and Mittelstädt 2011; Reifner 2011) or differ in their conceptualization from financial literacy and, thus, in the specific model of a financially educated person on which they are based (Aprea 2014). Referring to Aprea (2014), the following three types of conceptualizations ${ }^{2}$ can be derived:

- Manager of personal financial issues.

- Responsible consumer.

- Responsible economic citizens.

The most widespread conceptualization approach in research is aimed at personal financial management. The focus is primarily on individual financial decisions relating to private life and household management, such as the daily handling of money and loans, the insurance of life risks, the accumulation of assets, and old-age provisions. This approach focuses on economic subjects in their role as consumers, thereby reducing it to the consumer perspective (Aprea 2014). Nevertheless, this framework is the basis for a large number of studies and publications that focus on knowledge or competencies in the financial sector (Schlösser et al. 2011). With the mission of developing responsible consumers, personal financial management is extended to include the aspect of responsible consumption. The focus here is on the ability to critically reflect on one's own needs and purchase decisions and to control them in a targeted manner. The objective is the reduction of information asymmetries existing in consulting and sales situations. In addition, the rights and obligations of consumers in their relationships with other financial market players are relevant in this approach (Aprea 2014). Reifner's (2011) work is representative of this approach. In addition, the central idea of a responsible

\footnotetext{
2 The approaches described are an ideal type of bundling that is not free of overlaps. The allocation to the corresponding approaches is based on the main argumentation line (Aprea 2014).
} 
economic citizen includes in particular the embedding of personal financial decisions in an expanded and comprehensive context of economy and society; therefore, the main focus is not only on the consumer perspective. Thus, the approach presented here also includes monetary policy aspects and the relevant role of the state in this context. The regulation of financial markets and the influence of international interdependencies are also central issues. Not only are such macroeconomic aspects relevant for private financial decisions, but citizens are rather regarded as co-designers of institutional framework conditions and should be enabled to participate in the shaping of a democratically compatible economic and financial system. The conceptualization approach presented here is thus more comprehensive than the first two variants and can simultaneously be described as systemic because, as has been shown, it also includes a political dimension that goes well beyond the pure consumer perspective (Aprea et al. 2015; Aprea 2014). Only recent research projects and publications increasingly follow the comprehensive conceptualization approach of the responsible economic citizen described thus far (e.g., Aprea and Wuttke 2016; Kaminski and Friebel 2012; Retzmann and Seeber 2016). This approach is also taken up in this paper (see "Methods" section).

\section{Empirical findings}

In recent years, there has been an increase in the number of studies focusing on financial literacy of adolescents (e.g. Amagir et al. 2018; Aprea and Wuttke 2016; OECD 2017a; Rinaldi and Todesco 2012; Rudeloff 2019; Schürkmann 2017; Sohn et al. 2012). A lack of knowledge among the participants was identified in all studies. The PISA study from 2015, for example, shows that, despite differences in performance among countries, a large proportion of students have only a basic knowledge of financial literacy. On average, 22\% of students in OECD (Organisation for Economic Co-operation and Development) countries have skills below level 2, which is considered the baseline level ${ }^{3}$ (OECD 2017a); at best, these participants can only see the difference between needs and demands, make simple decisions about daily expenses, understand the purpose of everyday financial documents such as an invoice, and perform simple arithmetic operations (OECD 2014). The results of the Financial Literacy Study (FILS) (Schürkmann 2017), which used young people as a target group, also show that financial literacy varies depending on the subject area. Regardless of the type of school, students show weak skills in the areas of insurance and taxes, debt, and monetary policy whereas their skills in the areas of wealth formation and the use of online services are very pronounced in the majority of respondents.

For the analyses on which the article is based, however, not only previous study results on the state of financial literacy among young people are relevant, but also research results that identify variables related to financial literacy. On the one hand, research findings on informal learning opportunities have to be taken into account and, on the other hand, results on socio-economic and personal variables are relevant.

\footnotetext{
3 The requirements of the baseline level are the following aspects: Students can apply their knowledge of common financial products and commonly used financial terms and concepts. They can use given information to make financial decisions in contexts that are directly relevant to them. They understand the benefits of a budget and can interpret everyday financial documents. They can apply individual basic numerical operations, including division, to answer financial questions. They demonstrate an understanding of the relationships between different financial elements, such as costs and benefits (OECD 2014).
} 
Socio-economic and personal variables related to financial literacy are essential as control variables for this quantitative study (see "Methods" and "Results" sections). In order to identify possible informal learning opportunities related to financial literacy, studies on financial socialization (e.g. Grohmann et al. 2015; Jorgensen and Salva 2010; Shim et al. 2010, 2015; Solheim et al. 2011) and studies on the financial literacy of adolescents that take into account socialization aspects will be considered (e.g. OECD 2017a; Schürkmann 2017).

A multitude of empirical studies dealing with financial socialization focus on collecting retrospective data from young adults on financial experiences or interactions with their parents (e.g., Clarke et al. 2005; Kim and Chatterjee 2013; Shim et al. 2010). What the studies have in common is that they understand financial socialization as a process that extends from childhood to early adulthood, in which consumer roles are developed with the help of parents, teachers, friends, work experience and the media (Gudmunson et al. 2016). Overall, literature on financial socialization focuses on three or four socialization agents through which socialization takes place: family or parents, school, experiences at work and the media (Gudmunson and Danes 2011). The research mainly takes into account the first three socialization agents. For example, Studies by Shim et al. (2010, 2015) and Grohmann et al. (2015) analyze the correlation between parents, school and experiences at work and financial literacy. For example, Shim et al. (2010) confirmed that parents' direct instruction with regard to financial issues and decisions are significantly associated with their children's financial knowledge. The effect strengths of direct parental instruction compared to the other learning opportunities mentioned are approximately twice as high. At the same time, the study found that parents' financial behavior is often adapted and affects not only their behavior, but also the attitudes of children and adolescents toward finance. In addition, the 2015 PISA study highlights the relevance of parents' financial literacy to students' financial performance. According to the study, parents are crucial for the development of their children's financial attitudes, habits, and abilities as well as their financial knowledge. Parental financial literacy should therefore also be a focus of research and promotion. In ten countries, discussing financial matters with parents is accompanied by higher financial literacy, under the control of socio-economic status. This result underscores the importance of parental instructions (OECD 2017b). In addition, Shim et al. (2010) confirmed that teaching of financial content at school and work experience are significantly associated with children's financial knowledge. Grohmann et al. (2015) were able to replicate the presented results except for the effect of work experience. The effect of work experiences is primarily based on experiences of having money available on a regular basis. Overall, this effect must be viewed in a differentiated way. For example, Nyhus and Webley (2013) come to the following conclusion that doing chores for money and having a job as an adolescent is linked to having less intention to save. In addition, Nyhus and Webley (2013) conclude that working as an adolescent could be a prediction of holding high levels of debt later on in life.

The possession of an account or the regular handling of money is also associated with financial literacy. The results of the 2012 and 2015 PISA studies show that students who have a bank account or regularly receive gifts of money or pocket money 
achieve better results in the financial literacy tool (OECD 2014, 2017b). The results underline the influence of one's own experience in dealing with money, which was also replicated by Schürkmann (2017).

With regard to the personal and socio-economic background variables associated with financial literacy, a large number of empirical studies can be drawn upon (e.g. Bender 2012; Förster et al. 2018; OECD 2017a; Schürkmann 2017). The PISA studies from 2012 and 2015 (OECD 2014, 2017a) identified a positive correlation between financial literacy and skills in mathematics and reading. This effect has been proven in further studies on financial literacy, and a corresponding influence on basic cognitive skills has also been demonstrated (e.g., Grohmann et al. 2014; Herd et al. 2012). In addition, with the exception of a few studies (e.g., Mandell 2008), male learners have a knowledge advantage not yet sufficiently explained (e.g., Chen and Volpe 1998; Förster et al. 2018; Lusardi and Mitchell 2011).

At the same time, non-cognitive facets of competence are related to financial literacy. Thus a significant positive correlation between various motivational variables and financial literacy could be shown (Mandell and Klein 2007). The correlation between different positive and negative emotions and financial literacy, particularly between emotions and savings behavior, has also been empirically confirmed (e.g., Nenkov et al. 2009; Shahrabani 2012). Furthermore, a high subjective assessment of economic abilities is associated with better results in cognitive performance tests in the field of economics (Bender 2012). One's attitude toward money could also be identified as a significant positive regressor of financial literacy, albeit with only small effects (Schürkmann 2017).

Financial literacy is positively related to age (Atkinson and Messy 2012). The educational level and income of participants' parents are positively associated with financial literacy (e.g., Bucher-Koenen and Lusardi 2011; Lusardi and Mitchell 2011; Lusardi et al. 2009; Mandell 2008). The correlation between socio-economic status and financial literacy has also been considered in PISA and has been addressed through various aspects, such as the education and occupation of parents and their property relations. The results indicate the following relationship: Subjects whose family status can be assigned to a higher level are more likely to have a higher level of financial literacy. Moreover, a migration background is negativeliy associated with the test results (OECD 2014, 2017a).

In addition to the correlations mentioned thus far, a diploma or other certificate of graduation and the type of school are also connectet to financial literacy (Lusardi et al. 2009). In the PISA 2015 study, educational aspiration played a decisive role (OECD 2017b). Meanwhile, Bucher-Koenen and Lusardi (2011) demonstrated that participants' educational background correlated strongly with their financial literacy. The result allows the following interpretation: The lower the respondents' level of education, the more likely they were to have a lower financial literacy. Moreover, a positive attitude toward learning or an openness toward problem-solving aspects correlates positively with financial literacy (OECD 2014, 2017b).

With the help of the presented explanations, a number of correlation between background characteristics and financial literacy could be identified, as shown synoptically in Fig. 1. For the hypothesis to be formulated from the research question, informal learning opportunities are particularly focused. The other variables related to financial literacy, including the influence of the school, are considered as control variables. In terms of 


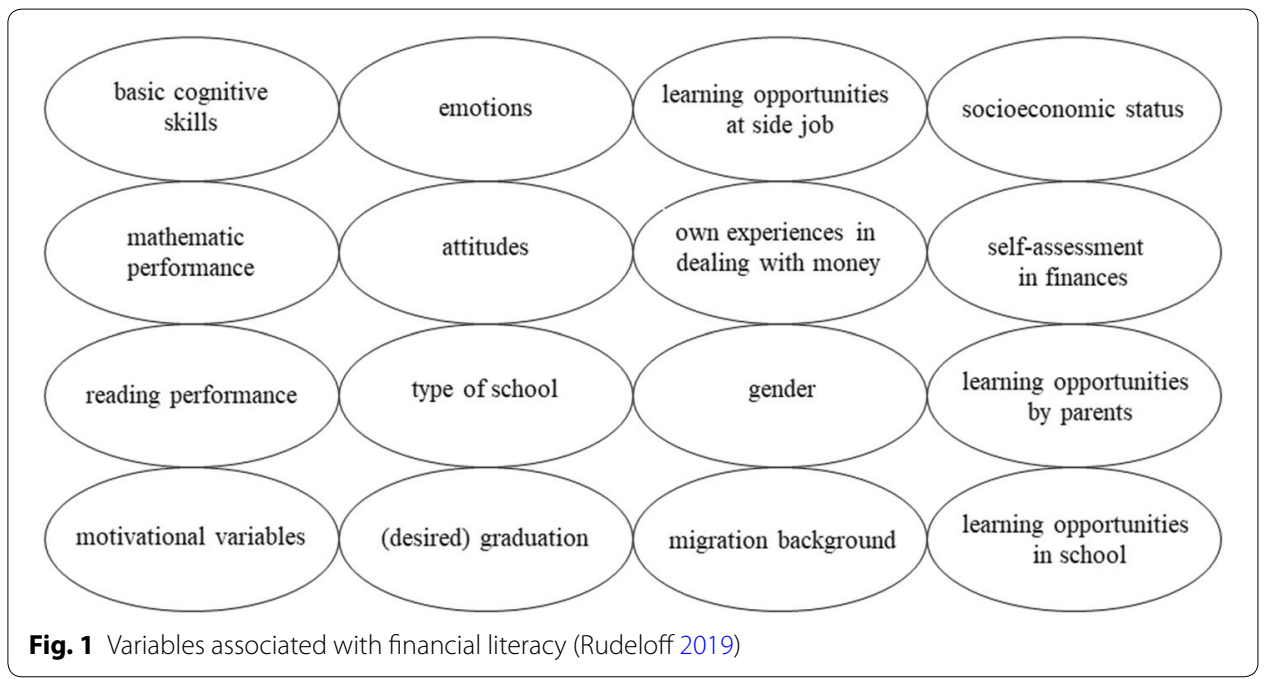

informal learning opportunities, the empirical findings show that parents in particular play a central role, but that factors such as work experience are also relevant. Furthermore, the influence of a number of other informal learning opportunities can also be assumed, especially because, in young people's world, further points of contact with financial topics and financial decisions become apparent, which can be the starting point for such learning processes (Rudeloff 2019). Examples include the different media (Reifner 2003). The following hypothesis can be derived from this understanding:

$\mathrm{H}$ : Financial literacy is influenced by informal learning opportunities. There are dimension-specific differences in the impact of informal learning opportunities.

The hypothesis was deliberately formulated in general terms, without naming specific learning opportunities, as there are currently insufficient empirical analyses that explore how certain informal learning opportunities affect young people's financial literacy.

\section{Methods}

\section{Operationalization of financial literacy}

Every measuring instrument/method to be used for the diagnosis of competencies is based on a theoretical competency model (Hartig and Klieme 2006). For such a competency model to serve as the foundation, it must be sufficiently specific with regard to the degree of abstraction (Fleischer et al. 2013). To this end, it is necessary to determine the corresponding competencies as well as the associated areas of action and their requirements as precisely as possible to ensure that a task construction oriented to these can be carried out within the framework of assessment development (Klotz 2015; Seeber 2016). The competency model at hand is based on structural and requirement-related assumptions about financial literacy. The basis for the development of this model is a cognitive-psychological understanding of competencies. Against this background and in consideration of new studies on financial literacy as well as Weinert's (2002) definition of competencies, financial literacy is regarded as a domain-specific construct. Financial literacy is understood as the interplay of knowledge, skills and abilities, motivational and emotional processes, and attitudes and self-efficacy expectations. This interplay of certain factors enables people to make well-founded decisions in financial contexts of 


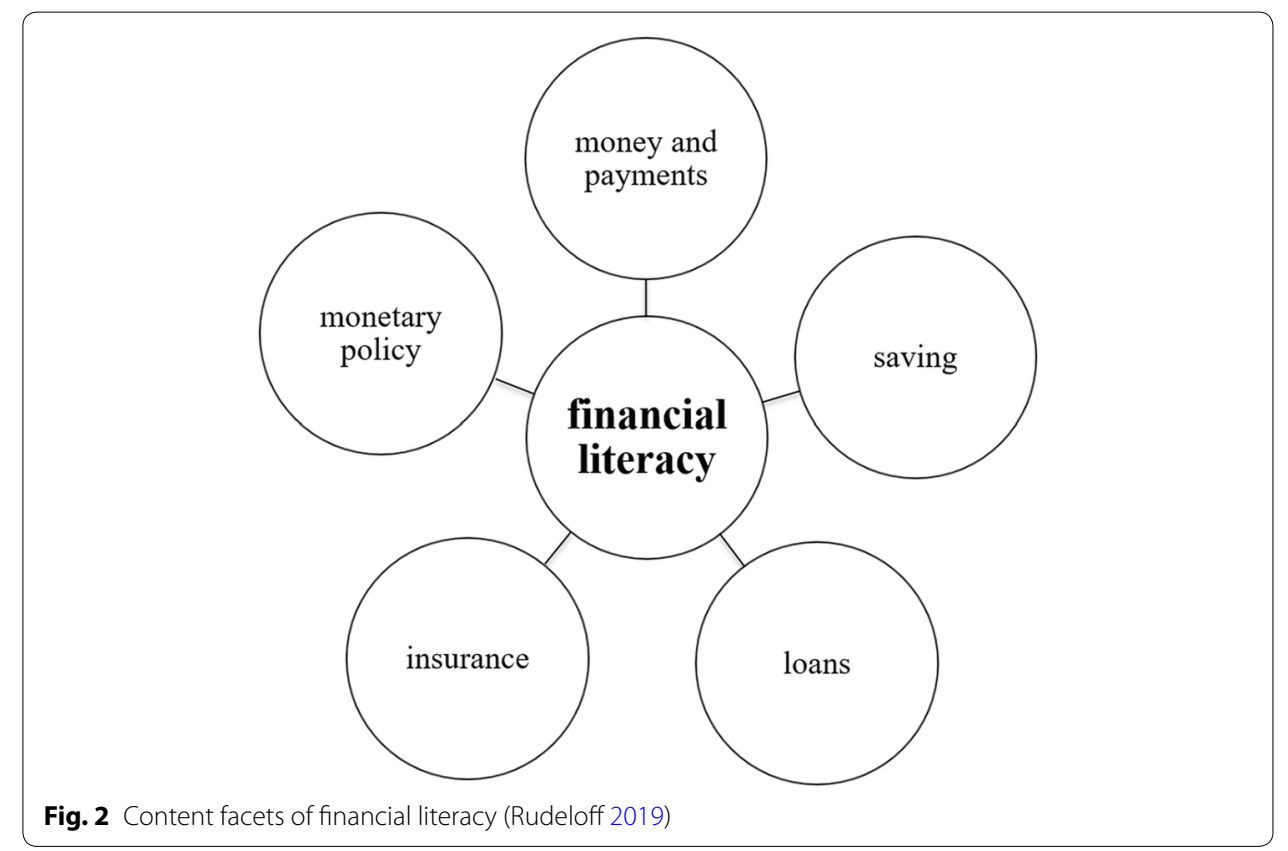

action in order to be able to participate in economic life as a responsible person. Individuals with pronounced financial literacy consider institutional and macroeconomic framework conditions in their decision-making process so that both individual and social well-being can be improved (OECD 2013; Rudeloff 2019). From a content-structural perspective, financial literacy is understood as a multi-perspectival construct based on the conceptualizations presented in the previous section. It refers to the comprehensive conceptualization approach of a responsible economic citizen (Aprea 2014). The definition of the contexts of action in financial economy is object-oriented and based on analyses by Kaminski and Friebel (2012), Seeber et al. (2012), Schürkmann (2017), Schürkmann and Schuhen (2013), and Walstad and Rebeck (2017). Consequently, there are five content facets (see Fig. 2), which were defined as free of overlap as possible.

The defined content facets of financial literacy form the basis for item development to capture the cognitive facet of financial literacy. Following Klieme and Leutner (2006, p. 880), the non-cognitive facets are captured separately.

\section{Sample and test instrument}

The following analyses are based on a sample of 530 secondary level 1 graduates drawn in Lower Saxony, Germany. Overall, 9.40\% of the students were aiming for a lower secondary school graduation certificate or diploma, $37.40 \%$ for a secondary modern school graduation certificate, $9.60 \%$ for a technical college entrance qualification, and $40.80 \%$ for a general higher education entrance qualification. In addition, $2.80 \%$ of the participants did not specify their intended school graduation certificate in detail. Of the participating students, $50.90 \%$ were female and $48.90 \%$ male, while $0.20 \%$ of the respondents did not report gender. If the variables country of birth, mother tongue, and nationality are considered together and combined to form a first-order migrant background, the proportion of respondents without a migrant background is $81.50 \%$. In addition, the 
migration background of the second order was considered by considering the countries of birth of the parents. In this case, $32.10 \%$ of the students surveyed have a migration background, ${ }^{4}$ whereas $66.60 \%$ do not. For $1.30 \%$ of the interviewees, the second order migration background could not be determined due to a lack of information.

A paper-based questionnaire was used, which was comprehensively validated and piloted (Rudeloff 2019, pp. 167-192). According to the developed multidimensional model of financial literacy, the test contained items for the following content dimensions: money/payments, savings, loans, insurance, and monetary policy. For each subdimension of financial literacy, the test included tasks of varying complexity in which the respondents - taking into account their different roles in the financial business-have to, for example, make or evaluate financial decisions. In order to systematically vary item difficulties, the test was based on items requiring different cognitive processes to solve and that differed with regard to the pre-structuring of the solution path, the number of possible solutions, and the extent of the variables to be processed that are relevant to the solution (Rudeloff 2019, pp 29-32; 113-114; Winther 2010, pp 167-192). The test included items using a free response format as well as multiple choice items. Assignment and selection tasks can be distinguished for tasks with a bound answer format; the latter tasks are designed as both dichotomous items and multiple-choice tasks. The item pool comprised 50 items. The non-cognitive facets of competence and the use of various learning opportunities were also recorded. Learning opportunity use was measured separately for each sub-dimension of financial literacy using a four-point Likert scale. In total, the following learning opportunities were surveyed, which were identified as such based on a qualitative study (Rudeloff 2019, p. 162): parents, siblings, friends, banks, insurance companies, schools, teachers, ${ }^{5}$ consumer associations, newspapers, (trade) magazines, radio and television broadcasts/reportages, news, internet (Google, Wikipedia, etc.), social networks (e.g., Facebook), advertisements from financial companies, (technical) books, internships, (side) jobs, and one's own experiences (shopping, having insurance, etc.). A field marked as "Other" opened up the possibility of indicating further learning opportunities and the corresponding intensity of use.

Table 1 gives an overview of all other scales used to record potentially relevant regressors. The already empirically tested variables related to financial literacy (cf. "Financial literacy in scientific discourse" section) are included to be able to make statements about construct validation as well as determine the influence of individual regressors, especially of learning opportunities, as precisely as possible without overestimating them.

From a methodological perspective, the cognitive facets of financial literacy (financial economic knowledge, financial economic skills and abilities) and non-cognitive characteristics (motivational variables, emotions, attitudes, expectations of self-efficacy) were recorded separately to ensure the individual facets could be examined with regard to

\footnotetext{
${ }^{4}$ See Settelmeyer and Erbe (2010) for the operationalisation of the migration background.

5 The separation between the learning opportunities teacher and school was carried out based on the results of Rudeloff's qualitative study (2019). The differentiation is justified by the fact that the teacher also imparts content beyond the subject matter of the lesson and also makes this expansion clear to the students, e.g. he reports on his private house financing. The learning opportunity school comprises exclusively curricularly embedded learning contents (e.g., interest calculation in mathematics). Since the focus of this article is on the influence of informal learning opportunities, the formal learning opportunities act as control variables.
} 
Table 1 Instruments used to record relevant predictors (Rudeloff 2019)

\begin{tabular}{ll}
\hline Construct & Origin of the instrument used \\
\hline Testing effort & Adaptation from PISA 2003 (Ramm et al. 2006) \\
Emotion & Adaptation of the PANAS scale by Breyer and Bluemke (2016) \\
Motivation & Adaptation by Prenzel et al. (1996) \\
Settings about money & Adaptation by Barry (2014) \\
Economic interest & Adaptation of Winther (2006) \\
Self-assessment & In-house development \\
Self-efficacy & Adaptation of Jerusalem and Schwarzer (1999) \\
Financial socialization by parents & Adaptation of Rosendorfer (2000) and in-house development \\
Personal and socio-economic factors & $\begin{array}{l}\text { Gender, year of birth, nationality, country of birth, mother } \\
\text { tongue, grades, possession of checking or savings account, } \\
\end{array}$ \\
receipt of pocket money, parents' country of birth, spoken \\
language in private household, number of books in parents' \\
house, intended school completion certificate, type of \\
school attended, parents'school completion certificate
\end{tabular}

their relationship to one another (Klieme and Hartig 2007, p. 54; Klieme and Leutner 2006, p. 880).

\section{Data analysis}

To test the hypotheses, a structural equation model was calculated in the software Mplus Version 7 (Muthén and Muthén 2012). The basis for the model specification was the five-dimensional model of financial literacy. The cognitive facet of financial literacy was represented as a latent variable by the participant's test performance $^{6}$ in the individual sub-dimensions of financial literacy (money/payments, savings, loans, insurance, monetary policy). According to the hypotheses, the influences of the different learning opportunities were tested dimension-specifically. Due to the separate measurement of the cognitive facet of financial literacy and non-cognitive characteristics, ${ }^{7}$ the latter characteristics were analyzed with regard to their relationship to the cognitive competence facet. The same applies to the personal and socio-economic background factors surveyed, which function as control variables.

Different indices were used to check the quality and fit of a structural equation model. The root mean square error of approximation (RMSEA) and the standardized root mean square residual (SRMR) were used as absolute goodness-of-fit indices whereas the comparative fit index (CFI) was used as a comparative goodness-of-fit index. For the RMSEA, values below 0.05 are considered good and values below 0.08 are still acceptable (Christ and Schlüter 2012). Values greater than 0.08 are also unacceptable with regard to the SRMR (Reinecke 2014). Values from 0.90 are sufficient for the CFI (Hartig et al. 2008).

\footnotetext{
${ }^{6}$ The test performances were represented as personal ability values, so-called weighted likelihood estimation (WLE) personal ability scores. These were generated using item response theory (IRT) methods. The basis was the calculation of a five-dimensional IRT model (Rudeloff 2019, p. 205).

7 A number of non-cognitive facets of competence have been modelled as latent constructs. For construct validation of these features, see Rudeloff (2019).
} 


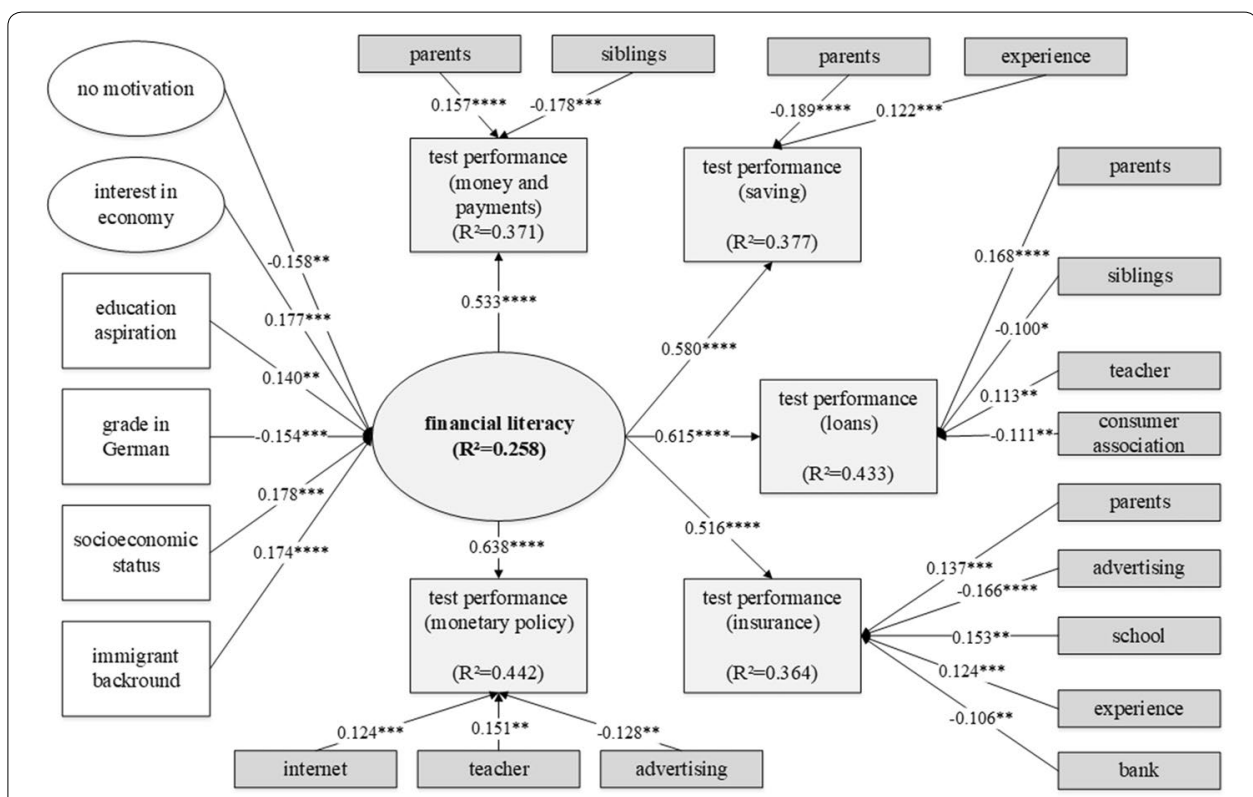

Fig. 3 Structural equation model. Significant level: ${ }^{* * *} \leq 0.001^{* * *} \leq 0.01{ }^{* *} \leq 0.05^{*} \leq 0.1$

\section{Results}

The structural equation model on which this paper is based is shown in Fig. 3. It is characterized by sufficient model fit (CFI: 0.91; RMSEA: 0.03; SRMR: 0.05), which speaks to the adequacy of the model, especially due to its high complexity. The model indicated that $25.80 \%$ of the variance of the test performance can be explained. With regard to the central research question of the paper, parents and siblings were found to be significantly related on test performance in the field of monetary and payment services. The result allows the following interpretation: The more students learned about money and payment transactions from their parents, the more likely they were to have good test results. Meanwhile, the more intensively the students learned from their siblings about money and payment transactions, the more likely they were to have lower test results.

In the sub-dimension "savings", siblings and personal experience in savings as learning opportunities are significantly associated with test performance. Based on the previous analyses, this could mean that the more intensively young people learned about the topic of savings from their siblings, they received lower test performance whereas personal savings experiences was positively connected to their performance.

For the test area concerning loans, parents, siblings, teachers, and consumer associations were found to be significant regressors as learning opportunities. Parents and teachers were significant positive regressors for the test performance in the subdimension "loans". Siblings and consumer associations as learning opportunities are negatively associated with the test results.

Significant positive regressors for the test results in the sub-dimension "insurance" were parents, school, and one's own experiences in insurance. In contrast, using information provided by banks or advertisers to learn about insurance are connected with lower test performance. 
In the sub-dimension "monetary policy", internet, teachers, and advertising as learning opportunities are significantly associated with test performance. A possible explanation could be that the more students learned about monetary policy on the internet or from a teacher, the more likely they were to have good test results. However, learning through advertising is negatively related to test performance.

Other background factors beyond learning opportunities proved to be significant as well. For instance, economic interest and socio-economic status (measured by the number of books in the household) were positively associated with the financial literacy test results. Higher test performance was also more likely if the participants had higher educational aspirations, no migration background in the second generation, and good grades in German. The negative correlation of the grade is due to the German grade scale from 1 (very good) to 6 (inadequate). The only negative link between financial literacy and motivational variables was found for participants who showed no motivation for the financial topic.

\section{Discussion}

The results of the structural equation analyses show that a number of informal learning opportunities are relevant for financial literacy. With regard to the question of which learning opportunities are significantly related to financial literacy, dimension-specific differences demonstrated a clear impact, leading to the retention of the hypothesis. Overall, the results underscore the importance of domestic learning contexts. Parents' influence on their children's financial abilities, which has already been proven in many studies on the financial socialization of children and adolescents (e.g., Grohmann et al. 2015; Jorgensen and Salva 2010; Shim et al. 2010, 2015; Solheim et al. 2011), was confirmed. Nevertheless, one's own experiences, which are often conveyed through the parents, are also relevant. Yet what is striking is the negative correlation between siblings as a learning opportunity and test performance. One possible explanation for this-although it cannot be empirically confirmed based on the data-is that preconcepts rather than well-founded knowledge arise in conversations with siblings, as siblings likely have comparable knowledge deficits. This interpretation is supported by the results of Rudeloff's (2019) qualitative study with young people from the same target group. However, additional analysis is needed to further investigate the effect. In addition, the age of the siblings was not included.

Beyond domestic learning opportunities, media learning opportunities play a crucial role. For example, the positive correlation between the internet as a learning opportunity and test performance can be interpreted as an indication that young people can distinguish between scientific and unscientific, correct and incorrect information, respectively, when researching on the internet or that valid information on the relevant search engines can lead to good hits with providers who offer reliable information. The first possible interpretation is supported by the results of Fleischer and Hajok (2019), who point out that young people develop information and research skills through early contact with digital media and personal (and school-inspired) information needs, which enable them to adequately search for, select, reduce and process information as they enter adolescence. The negative connection between advertising and test results, which has been repeatedly demonstrated, may be due 
to the selective presentation of insurance policies and benefits in media offerings. The negative correlation between consumer association as a learning opportunity and test performance is surprising, especially as some consumer associations aim to promote financial literacy (Kaminski and Friebel 2012). However, it should be noted that, although the consumer association variable was surveyed as a potential learning opportunity, the term itself was not further specified in the questionnaire. As a result, it cannot be ruled out that prevailing misconceptions with regard to the understanding of the term may have caused the negative impact, although this cannot be confirmed or refuted on the basis of the available data.

Furthermore, the effect of banks as a learning opportunity does not appear to be in line with expectations, at first glance. It could be explained, albeit only based on assumptions, by the fact that relevant information, especially on the subject of insurance, is not processed in an age-appropriate manner within the scope of consultations with banks or in information brochures, so that preconcepts or misconceptions may possibly arise. Bank-specific interests aimed at taking out insurance could also influence the design of information (Loerwald and Retzmann 2011).

Despite their relevance in other empirical studies, some learning opportunities were not significant regressors for test performance in the area of financial literacy for our sample, which is a striking result. For example, no effect was found from learning within a side job. This finding does not reflect the results on financial socialization according to which a side job has a positive impact on financial literacy (Shim et al. 2010). However, no negative correlation between facets of financial literacy and work experience (as found by the study by Nyhus and Webley (2013)) can be replicated. In future studies, the influence of a side job should be examined in more detail.

This study also has limitations. Thus, on the basis of the available results, no differentiated statement can be made about the way in which the various learning opportunities are used. In the study, students rated the learning opportunities on a Likert scale, thus, it was only asked how intensely each learning opportunity was used to acquire financial literacy in a particular sub-dimension. However, this kind of rating does not allow for information on the kind of usage of the learning opportunities. In addition, the learning opportunities were not specified in more detail, which seems rather unproblematic for typical learning opportunities, such as parents, friends, and siblings, but is necessary for learning opportunities such as consumer associations or even one's own experiences in order to be able to interpret the results more effectively. Nor is it possible to say what determines the use of learning opportunities and to what extent differences in the nature of learning opportunities are apparent. Although it is assumed that informal learning processes are subject to stronger social stratification factors than school-based and thus formal learning (Aprea 2012; Stecher 2005), further analyses are necessary. Overall, the conditions under which non-institutionally organized learning processes (can) take place need to be examined more closely. In addition, the quality of individual learning opportunities also needs to be decisively examined.

If, additionally, the variance elucidation is considered, $25.80 \%$ can be elucidated with the help of the calculated structural equation model. Consequently, the proportion of unexplained variance is well over $50.00 \%$ so that other influencing factors not 
considered or adequately surveyed in this study are relevant for differences in test performance among young people. In future research projects, it will be necessary to identify further variables related to financial literacy.

At the same time, it should be noted that the assumptions about directions of influence that are reflected in the model as directional relationships between the variables cannot be confirmed at this point. The present findings can only be interpreted against the background of this limitation. However, this limitation applies to a large number of statistical methods. Analyses to confirm causal assumptions, for example, require at least additional consideration of a temporal perspective of data collection. This could be achieved either by longitudinal investigations or by temporally preceding experimental manipulation, which would, however, require the control of interfering variables (Döring and Bortz 2016).

\section{Conclusion}

The results reported highlight the importance of different learning opportunities for the development of financial literacy. They also underline the necessity of financial socialization. As adolescents seem to benefit from conversations with their parents, the financial literacy of parents should become a focus of further research. One important question is how parents can be supported in their endeavor to teach their children about financial issues. From a practical point of view, parents could also be supported more systematically in their endeavours. One starting point could be the promotion of parents' financial literacy. At the same time, it is necessary to examine in more detail which strategies parents use to teach their children how to deal with finances and how different approaches work, also taking into account personal and socio-economic background factors.

The test instrument which was used for this paper can be adapted to different age groups. It could be used to assess the parents' financial literacy to find out more about how the level of the parents' financial literacy relates to the adolescents' financial literacy. At the same time, the test instrument could support the process of financial socialisation. For example, the tests could be further developed as a learning tool including instructions, solutions to the tasks and detailed explanations so that parents and adolescents could develop their financial literacy together.

Regarding the media-based learning opportunities, it would be also possible to use the test instrument as a basis for the development of a computer-based learning tool for parents and adolescents alike. To put this practical implication into action, however, it is necessary to further investigate in advance how the different media learning opportunities are associated with. Of course, for this endeavor, current research about the design of digital media and its impact on learning outcomes (e.g., Süss et al. 2018) needs to be taken into account.

Overall, the results presented in this paper extend the state of research on financial literacy by systematically investigating the importance of different informal learning opportunities. The research needs to be extended (beyond the suggestions above), for example, by examining the quality and the actual use of the different learning opportunities. Overall, the current study already provides some important implications for the promotion of financial literacy in different informal learning situations. Finally, systematic strategies need to be developed to promote financial literacy in extracurricular 
activities as well as for lessons in school. However, the latter formal form of teaching requires a sufficient curricular embedment of financial content, which in turn requires a revision of the curricula.

\section{Abbreviations}

CFI: comparative fit index; FILS: Financial Literacy Study; IRT: item response theory; OECD: Organisation for Economic Cooperation and Development; PISA: Programme for International Student Assessment; RMSEA: root mean square error of approximation; SRMR: standardized root mean square residual; WLE: weighted likelihood estimation; WMNSQ: weighted mean square.

\section{Acknowledgements}

I am indebted to the two anonymous reviewers who provided constructive feedback and helpful guidance in the revision of this paper. At the same time, I would like to thank Taiga Brahm for her support and constructive feedback.

\section{Authors' contributions}

The author made substantial contributions to the conception and design of the study. The author took responsibility for data analysis, interpretation and discussion of results. Further, she developed the test instrument for the study, which is described in the study. The author read and approved the final manuscript.

\section{Funding}

Not applicable.

\section{Availability of data and materials}

All data are available from the author.

\section{Ethics approval and consent to participate}

The study is examined and approved by the ministry of Lower Saxony. Participants were informed about the aim of the study and that their participation was anonymous and voluntary.

\section{Competing interests}

The author declares no competing interests.

Received: 4 January 2019 Accepted: 1 October 2019

Published online: 07 October 2019

\section{References}

Amagir A, Wilschut A, Groot W (2018) The relationship between financial knowlegde, attitudes towards money, financial self-efficacy, and financial behavior among high school students in the Netherlands. Empirische Pädagogik 32(3):387-400

Aprea C (2012) Messung der Befähigung zum Umgang mit Geld und Finanzthemen. Ausgewählte Instrumente und alternative diagnostische Zugänge. http://www.bwpat.de/ausgabe22/aprea_bwpat22.pdf. Accessed 14 Nov 2018

Aprea C (2014) Finanzielle Allgemeinbildung: Entwurf einer bildungstheoretisch verankerten Konzeptualisierung. ZfDG 5(2):68-89

Aprea C, Wuttke E (2016) Financial literacy of adolescents and young adults: setting the course for a competenceoriented assessment instrument. In: Aprea C, Wuttke E, Breuer K, Keng Koh N, Davies P, Greimel-Fuhrmann B, Lopus J (eds) International handbook of financial literacy. Springer, Singapore, pp 397-414

Aprea A, Wuttke E, Leumann S, Heumann M (2015) Kompetenzfacetten von Financial Literacy: Sichtweisen verschiedener Akteure. In: Seifried J, Seeber S, Ziegler B (eds) Jahrbuch der berufs- und wirtschaftspädagogischen Forschung 2015. Budrich, Opladen, pp 11-22

Atkinson A, Messy F (2012) Measuring financial literacy: results of the OECD/International Network on Financial Education (INFE) pilot study. http://dx.doi.org/10.1787/5k9csfs90fr4-en. Accessed 20 Dec 2018

Barry D (ed) (2014) Die Einstellungen zu Geld bei jungen Erwachsenen. Springer, Wiesbaden

Bender N (ed) (2012) Selbstreguliertes Geldmanagement bei jungen Erwachsenen. Peter Lang, Frankfurt am Main

Breyer B, Bluemke M (2016) Deutsche Version der Positive and Negative Affect Schedule PANAS (GESIS Panel). Zusammenstellung sozialwissenschaftlicher Items und Skalen. https://doi.org/10.6102/zis242

Bucher-Koenen T, Lusardi A (2011) Financial literacy and retirement planning in Germany. http://www.nber.org/papers/ w17110.pdf. Accessed 20 Dec 2018

Chen H, Volpe R (1998) An analysis of personal financial literacy among college students. Finance Serv Rev 7(2):107-128

Christ O, Schlüter E (2012) Strukturgleichungsmodelle mit Mplus: eine praktische Einführung. Oldenbourg Verlag, München

Clarke MC, Heaton MB, Israelson CL, Egett DL (2005) The acquisition of family financial roles and responsibilities. Fam Consum Sci Res J 33(4):321-340. https://doi.org/10.1177/1077727×04274117

Commission of the European Communities (2000) Memorandum über Lebenslanges Lernen. https://www.hrk.de/uploa ds/tx_szcon-vention/memode.pdf. Accessed 20 July 2018

Commission of the European Communities (2001) Making a European area of lifelong learning a reality. http://www. europarl.europa.eu/meetdocs/committees/cult/20020122/com(2001)678_en.pdf. Accessed 20 Jul 2018

Döring N, Bortz J (2016) Forschungsmethoden und Evaluation in den Sozial- und Humanwissenschaften, 5th edn. Springer, Heidelberg 
Düx W, Rauschenbach T (2010) Informelles Lernen im Jugendalter. In: Neuber N (ed) Informelles Lernen im Sport. Verlag für Sozialwissenschaften, Wiesbaden, Beiträge zur allgemeinen Bildungsdebatte, pp 53-77

Fleischer S, Hajok D (2019) Medienbildungsprozesse. In: Kracke B, Noack P (eds) Handbuch Entwicklungs- und Erziehungspsychologie. Springer Reference Psychologie. Springer, Berlin, Heidelberg, pp 181-206

Fleischer DPJ, Koeppen K, Kenk, DPM, Klieme E, Leutner D (2013) Kompetenzmodellierung: Struktur, Konzepte und Forschungszugänge des DFG Schwerpunktprogramms. Zeitschrift für Erziehungswissenschaft 16(1):5-22

Förster M, Happ R, Maur A (2018) The relationship among gender, interest in fi-nancial topics and understanding of personal finance. Empirische Pädagogik 32(3):293-309

Grohmann A, Kouwenberg R, Menkhoff L (2014) Roots of financial literacy. Paper presented at the Jahrestagung des Vereins für Socialpolitik 2014: Evidenzbasierte Wirtschaftspolitik - Session: Causes and Consequences of Financial (II) literacy, No. G10-V3, Hamburg, 7-10 September 2014

Grohmann A, Kouwenberg R, Menkhoff L (2015) Childhood Roots of Financial Literacy. J Econ Psychol 51:114-133

Gudmunson CG, Danes SM (2011) Family financial socialization: theory and critical review. J Fam Econ Issues 32(4):644667. https://doi.org/10.1007/s10834-011-9275-y

Gudmunson CG, Ray SK, Xiao JJ (2016) Financial socialization. In: Xiao JJ (ed) Handbook of consumer finance research. Springer Publishing, New York, pp 61-72

Harring M, Witte MD, Burger T (2016) Informelles Lernen - Eine Einführung. In: Harring M, Witte MD, Burger T (eds) Handbuch informelles Lernen. Interdisziplinäre und internationale Perspektiven, Beltz Juventa, Weinheim, pp 12-27

Hartig J, Klieme E (2006) Kompetenz und Kompetenzdiagnostik. In: Schweizer K (ed) Leistung und Leistungsdiagnostik. Springer, Berlin, pp 127-144

Hartig J, Jude N, Wagner W (2008) Methodische Grundlagen der Messung und Erklärung sprachlicher Kompetenzen. In: DESI-Konsortium (eds) Unterricht und Kompetenzerwerb in Deutsch und Englisch: Ergebnisse der DESI-Studie. Beltz, Weinheim, pp 34-54

Herd P, Holden K, Su YT (2012) The links between early-life cognition and schooling and late-life financial knowledge. J Consum Aff 46:411-435. https://doi.org/10.1111/j.1745-6606.2012.01235.x

Jerusalem M, Schwarzer R (1999) Allgemeine Selbstwirksamkeit. In: Schwarzer R, Jerusalem M (eds) Skalen zur Erfassung von Lehrer- und Schülermerkmalen. Freie Universität Berlin, Berlin, pp 13-14

Jorgensen B, Salva J (2010) Financial literacy of young adults: the importance of parental socialization. Fam Relat 59(4):465-478. https://doi.org/10.1111/j.1741-3729.2010.00616.x

Kaminski H, Friebel S (eds) (2012) Finanzielle Allgemeinbildung als Bestandteil der ökonomischen Bildung. Institut für Ökonomische Bildung an der Universität Oldenburg, Oldenburg

Kim J, Chatterjee S (2013) Childhood financial socialization and young adults'financial management. J Finance Couns Plan 24(1):61-79

Klieme E, Hartig J (2007) Kompetenzkonzepte in den Sozialwissenschaften und im erziehungswissenschaftlichen Diskurs. In: Prenzel M, Gogolin I, Krüger HH (eds) Kompetenzdiagnostik, Zeitschrift für Erziehungswissenschaft Sonderheft 8. VS Verlag für Sozialwissenschaften, Wiesbaden, pp 11-29

Klieme E, Leutner D (2006) Kompetenzmodelle zur Erfassung individueller Lernergebnisse und zur Bilanzierung von Bildungsprozessen. Beschreibung eines neu eingerichteten Schwerpunktprogramms der DFG. ZfPäd 52(6):876-903

Klotz VK (ed) (2015) Diagnostik beruflicher Kompetenzentwicklung: Eine wirtschaftsdidaktische Modellierung für die kaufmännische Domäne. Springer Gabler, Wiesbaden

Liening A, Mittelstädt E (2011) Börsen - Planspiele - Leuchttürme oder Irrlichter der finanziellen Allgemeinbildung? In: Retzmann T (ed) Finanzielle Bildung in der Schule. Wochenschau, Schwalbach/Ts, pp 99-114

Loerwald D, Retzmann T (2011) Falschberatung durch Banken als Gegenstand des Ökonomieunterrichts? Eine wirtschaftsdidaktische Analyse in Anbetracht der Finanzkrise. In: Retzmann T (ed) Finanzielle Bildung in der Schule. Mündige Verbraucher durch Konsumentenbildung, Wochenschau, Schwalbach/Ts, pp 79-100

Lusardi A, Mitchell OS (2011) Financial literacy around the world: an overview. J Pension Econ Finance 10(4):497-508. https://doi.org/10.1017/S1474747211000448

Lusardi A, Mitchell OS, Curto V (2009) Financial literacy among the young. Evidence and implications for consumer policy. http://www.nber.org/papers/w15352.pdf?new_window=1. Accessed 20 Dec 2018

Macha K, Neubauer M, Rehm M, Schuhen M (2011) Informelles Lernen und Ökonomische Bildung. In: Schlösser H-J, Schuhen M (eds) Siegener Beiträge zur Ökonomischen Bildung. ZöBiS, Siegen

Mandell L (2008) The financial literacy of young American adults. Results of the 2008 National Jump\$tart Coalition Survey of High School Seniors and College Students. http://www.jumpstart.org/assets/files/2008SurveyBook.pdf. Accessed 12 Nov 2018

Mandell L, Klein LS (2007) Motivation and financial literacy. http://citeseerx.ist.psu.edu/viewdoc/download;jsessionid =BC5E7C06E1099D79322D2C92B06DE29E?doi=10.1.1.392.2771\&rep=rep1\&type=pdf. Accessed 26 Oct 2018

Marsick V, Watkins K (1992) Towards a Theory of Informal and Incidental Learning in Organizations. Int J Lifelong Educ 11(4):287-300

Muthén LK, Muthén BO (2012) Mplus 7. Muthén \& Muthén, Los Angeles

Nenkov GY, MacInnis DJ, Morrin M (2009) How do emotions influence saving behavior? http://crr.bc.edu/wp-content/ uploads/2009/04/IB_9-8_508.pdf. Accessed 20 Dec 2018

Nyhus EK, Webley P (2013) The relationship between parenting and the economic behavior and orientation of norwegian adolescents. J Genet Psychol 174:620-641

OECD (ed) (2013) PISA 2012 assessment and analytical framework. Mathematics, reading, science, problem solving and financial literacy. OECD Publishing, Paris

OECD (2014) PISA 2012 results: students and money: financial literacy skills for the 21st century (Volume VI). OECD Publishing, Paris

OECD (ed) (2017a) PISA 2015 results. Students' financial literacy (Volume VI). OECD Publishing, Paris

OECD (2017b) What do 15-year-olds really know about money? http://dx.doi.org/10.1787/21dc1a9a-en. Accessed 20 Dec 2018 
Overwien B (2000) Informelles Lernen erforschen. Definitionen(en), Vorgehensweisen und Ergebnisse. In: Dehnbostel P, Novak H (eds) Arbeits- und erfahrungsorientierte Lernkonzepte. Bielefeld, Bertelsmann, pp 160-171

Prenzel M, Kristen A, Dengler P, Ettle R, Beer T (1996) Selbstbestimmt motiviertes und interessiertes Lernen in der kaufmännischen Erstausbildung. In: Beck K, Heid H (eds) Lehr-Lern-Prozesse in der kaufmännischen Erstausbildung. Wissenserwerb, Motivierungsgeschehen und Handlungskompetenzen. Steiner, Stuttgart, pp 47-49

Ramm G, Prenzel M, Baumert J, Blum W, Lehmann R, Leutner D, Neubrand M, Pekrun R, Rolff HG, Rost J, Schiefele U (2006) PISA 2003. Dokumentation der Erhebungsinstrumente. https://www.iqb.hu-berlin.de/fdz/studies/PISA-2003/ PISA_Skalen_160.pdf. Accessed 20 Dec 2018

Reifner U (2003) Finanzielle Allgemeinbildung: Bildung als Mittel der Armutsprävention in der Kreditgesellschaft. BadenBaden, Nomos

Reinecke J (2014) Strukturgleichungsmodelle in den Sozialwissenschaften. Oldenbourg Verlag, München

Reifner U (2011) Finanzielle Allgemeinbildung und ökonomische Bildung. In: Retzmann T (ed) Finanzielle Bildung in der Schule. Wochenschau, Schwalbach/Ts

Retzmann T, Seeber G (2016) Financial education in general education schools: A competence model. In: Aprea C, Wuttke E, Breuer K, Keng Koh N, Davies P, Greimel Fuhrmann B, Lopus J (eds) International handbook of financial literacy. Springer, Singapore, pp 9-23

Rinaldi E, Todesco L (2012) Financial literacy and money attitudes: do boys and girls really differ? A study among Italian preadolescents. Ital J Sociol Educ 2:143-165

Rosendorfer T (ed) (2000) Kinder und Geld. Gelderziehung in der Familie, Campus, Frankfurt am Main

Rudeloff M (2019) Der Einfluss informeller Lerngelegenheiten auf die Finanzkompetenz von Lernenden am Ende der Sekundarstufe I. Springer, Wiesbaden

Schlösser HJ, Neubauer M, Tzanova P (2011) Finanzielle Bildung. Politik und Zeitgeschichte 2011 (12):21-27

Schuhen M, Kunde FN (2015) Informelles Lernen und ökonomische Bildung. In: Rohs M (ed) Handbuch Informelles Lernen. Springer, Heidelberg

Schürkmann S (ed) (2017) FILS: Financial Literacy Study Validierung und Analyse einer schülerorientierten Financial Literacy. De Gruyter Oldenburg, Berlin

Schürkmann S, Schuhen M (2013) Kompetenzmessung im Bereich financial literacy. ZföB 1:73-89

Seeber S (2016) Vom Domänenmodell zum Kompetenzmodell: Konturen eines Assessmentdesigns zur Messung beruflicher Fachkompetenzen bei Medizinischen Fachangestellten. http://www.bwpat.de/profil4/seeber_profil4.pdf. Accessed 20 Dec 2018

Seeber G, Retzmann T, Remmele B, Jongebloed H-C (eds) (2012) Bildungsstandards der ökonomischen Allgemeinbildung. Kompetenzmodell - Aufgaben - Handlungsempfehlungen. Wochenschau, Schwalbach/Ts

Settelmeyer A, Erbe J (2010) Migrationshintergrund. Zur Operationalisierung des Begriffs in der Berufsbildungsforschung. https://www.bibb.de/dokumente/pdf/wd_112_migrationshintergrund.pdf. Accessed 14 Nov 2018

Shahrabani S (2012) The effect of financial literacy and emotions on intent to control personal budget: a study among Israeli college students. Int J Econ Finance. https://doi.org/10.5539/ijef.v4n9p156

Shim S, Barber BL, Card NA, Xiao JJ, Serido J (2010) Financial socialization of first-year college students: the roles of parents, work, and education. J Youth Adolesc 39(12):1457-1470. https://doi.org/10.1007/s10964-009-9432-x

Shim S, Serido J, Tang C, Card N (2015) Socialization process and pathway to healthy financial development for emerging adults. J Appl Dev Psychol 38:29-35

Sohn SH, Joo SH, Grable JE, Lee S, Kim M (2012) Adolescents' financial literacy: the role of financial socialization agents, financial experiences, and money attitudes in shaping financial literacy among South Korean youth. J Adolesc 35(4):969-980

Solheim C, Zuiker V, Levchenko P (2011) Financial socialization family pathways. Fam Sci Rev 16(2):97-112

Stecher $L$ (2005) Informelles Lernen bei Kindern und Jugendlichen und die Reproduktion sozialer Ungleichheit. ZfE 8(3):374-393. https://doi.org/10.1007/s11618-005-0146-x

Süss D, Lampert C, Trültzsch-Wijinen C (2018) Medienpädagogik. Ein Studienbuch zur Einführung, 3rd edn. Springer VS, Wiesbaden

Walstad WB, Rebeck K (2017) The test of financial literacy: development and measurement characteristics. J Econ Edu 48(2):113-122

Weinert FE (2002) Vergleichende Leistungsmessung in Schulen - eine umstrittene Selbstverständlichkeit. In: Weinert F (ed) Leistungsmessungen in Schulen, 2nd edn. Beltz, Weinheim, pp 17-31

Winther $\mathrm{E}$ (ed) (2006) Motivation in Lernprozessen. Konzepte in der Unterrichtspraxis von Wirtschaftsgymnasien, DUV, Wiesbaden

Winther E (ed) (2010) Kompetenzmessung in der beruflichen Bildung. Bertelsmann, Bielefeld

\section{Publisher's Note}

Springer Nature remains neutral with regard to jurisdictional claims in published maps and institutional affiliations. 